\title{
BARRIERS, BORDERS AND CROSSINGS IN TWO POSTMODERN NOVELS: \\ CARYL PHILLIPS'S THE NATURE OF BLOOD AND ZADIE SMITH'S WHITE TEETH
}

\author{
Cecilia Acquarone \\ Universidad de Centro Educativo Latinoamericano (Rosario, Argentina) \\ acquarone@ciudad.com.ar
}

\begin{abstract}
The present article is a study of the novels the Nature of Blood by Caryl Phillips and White Teeth by Zadie Smith as paradigmatic examples of postmodern writing as well as of two different responses that the movement has elicited in our times. While The Nature of Blood deals tragically with the postmodern condition, White Teeth laughs at the contradictions and celebrates the achievements of postmodernism.
\end{abstract}

Key Words: Postmodernism, Modernism, Postcolonialism, Novel

\section{RESUMEN}

El presente artículo analiza las novelas The Nature of Blood de Caryl Phillips y White Teeth de Zadie Smith como ejemplos paradigmáticos de escritura postmoderna así como de las diferentes reacciones que el movimiento ha suscitado. Mientras que The Nature of Blood presenta la condición postmoderna desde la tragedia, White Teeth hace uso de la comedia para ironizar sobre sus contradicciones y celebrar sus aciertos.

Palabras Clave: Postmodernismo, Modernismo, Postcolonialismo, Novela 
The complexity of the relations between modernism and postmodernism is reflected in the many discussions over the definition of the terms and over the relation between the two movements. The issues have kept theorists busy for the last decades with little agreement having been reached.

However, and in spite of the disagreements among theorists, we can discern a recurrent insistence on the superposition of the postulates of both modernism and postmodernism as well as a highlighting of the pertinence of the debate over power relations in reference to knowledge, civilization and progress.

The serious issues at stance in the modern/postmodern debate have received different treatment by various theorists: while there are some who evaluate them positively, others see them pessimistically, highlighting their negative implications. Bauman (1987), for example, sees modernism as a historical error, as the pursuit of a false track. He traces the pessimistic view of postmodern intellectuals to the crisis of European civilization and to the loss of their position as moral legislators in the west. Similarly, Hutcheon (1999) sustains that the male intellectual's apocalyptic conception of the dispersal of the ego may be ascribed to a subconscious phallocentric disappointment at his loss of centrality. On the other hand, other theorists celebrate what they consider to be achievements of postmodernism. Vattimo sees in the irruption of the electronic means of mass communication a great hope for the future since they make the conception of history as unitary process impossible. Instead, he holds they produce a multiplication of conceptions of the world which favours freedom and gives a voice to minorities. As such, this process should be celebrated as emancipatory. On the same lines, and sustaining gender specifications, Hutcheon sees in the postmodern female intellectual a celebratory mood at her liberation from patriarchal metanarratives and a brighter spirit than that of her male counterpart who regrets the loss of his dominant position.

To the vast, complex and heterogeneous arguments that constitute the field of studies of modernism and postmodernism still another interrelated thread can be interwoven. This is the area of studies known as postcolonialism, which stems from the same philosophical postulates as postmodernism both being postructuralist movements. In the present article, postcolonialism will be dealt with as derived from the same underlying philosophical preoccupations as postmodernism since both movements develop round the criticism (or alternatively re-inscription) of modern viewpoints as seen in their preference for heterogeneity over homogeneity, of hybridity over racism, of relativity over dogmatism, of pluralities and multivocality over binary oppositions. Such opposites are the centre of interest in both postmodernism and postcolonialism in the fields of identity, history and subjectivity, all of which are theorized from a linguistic and specifically narratological perspective by Lyotard, Hutcheon and White.

As paradigmatic examples of current postmodern writing, The Nature of Blood by Caryl Phillips and White Teeth by Zadie Smith express the paradoxes and contradictions that stand at the core of the relation between modernism and postmodernism illustrated by the lexeme «postmodern» which both contains and oversteps the lexeme «modern». Moreover, if we place the novels The Nature of Blood by Caryl Phillips and White Teeth by Zadie Smith in the above context of the apocalyptic versus the celebratory view of postmodernity, we can see that while The Nature of Blood can come to illustrate the tragic view of the male who suffers from his irrevocable loss of centrality and autonomy in 
the postmodern world, White Teeth offers a comic response to the challenges of postmodernity. While Phillips focuses on and criticises the modern version of Cartesian dualism with its corresponding hierarchical classification of entities, its crusade for purity and the imposition of insurmountable borders, Smith celebrates hybridity and liminality with their institution of cleavages and gaps where individual choice is possible. Both novels insert themselves within the issues raised by postcolonial studies and deal with the lot of unprivileged groups subjected to imperial policies. In the worlds described, oppression is opposed to subversion, restriction to freedom and tragedy to comedy. Phillips describes the tragic nature of a world in which dualism favoured evaluative judgements and led to the classification of genders, nations, races and religions. This hierarchical stratification, experienced as natural and commonsensical fostered the expansion of empires, the development of colonialism and the subsequent experience of diaspora.

Smith's novel, starting at the time when The Nature of Blood ends, depicts a different world in which relativism and ambivalence demolish hierarchies and allow for freedom and choice. Mutability and fluctuation lead to contradiction and inversion of meaning. At the same time, the novel favours the union of heterogeneous elements, the shattering of the conventional, the transgression of borders and the consequent possibility of the construction of an alternative reality. The celebration of difference and the transgression of borders liberate the spirit to laughter in a carnival pageant that brings echoes of the festive folk spirit (Bakhtin 1984).

Smith's and Phillips's positions come to enact two different ways of conferring meaning on similar realities that concern the unequal distribution of power within society. A fundamental postmodern theoretical postulate underlies their endeavour: language and narrative constitute the basis of the construction of meaning in culture. It is through telling stories to ourselves that we give meaning to our own lives and to the world around. Raw data call for the imposition of cultural models that confer coherence and significance upon them. Such models are typified in the logic of tropes and in the form of generic structures, which rescue facts from the chaos of experience and save them from oblivion (White 1999: 1-4). Owing to their concern with present and past circumstances, both Smith and Phillips become involved with the interpretation of historical situations. According to Hayden White (6), there is a fundamental similarity between the task of the novelist and that of the historian since both operate by organizing data through the structure of language though one does so over fictional and the other over real events. The textual operation described implies both the presence of a referent and of «intentionality» (7), elements which simultaneously activate the referential and the poetic function in both kinds of texts. Both the artist and the historian make use of linguistic tropes and fictional forms as logical modes of conferring coherence and hence meaning to their texts and to the situations they describe. Such fictional choices correspond to identifiable mythical archetypes and «figure forth different meanings -moral, cognitive, or aesthetic-within different fictional matrices» (White 1985: 127). According to White (1992: 60) discourse is a device for the production of meaning rather than a mere vehicle to transmit information on an external referent. A change in form will not produce modifications on the referential content but will affect its signification. No set of events (fictional or real) are humorous or tragic by nature, it is the narrator's imposition of a certain pre-existing generic model on his/her material that will determine the general 
tone of the text (9). The affirmations above highlight the basically interpretative character of all narrative writing or even of all writing itself. Since, together with Lyotard (1979), we recognize that the difference between narrative and scientific writing is in fact mythical as long as science makes use of narrative to legitimize itself.

The logical consequence of this line of argument comes to be that, if the historian is working on the same epistemological basis as the novelist, history is as imaginary and mythical as fiction itself. This is not to say that historical facts did not have actual existence at the time of their occurrence but that all history is interpretation and, moreover ideologically loaded as a consequence of which it can become a naturalizing instrument. On this basis, White (1992: 107) explains the function of narrative in society as that of creating a specific type of reading subject capable of adapting to the social system of the particular historical period to which he belongs. When this process aims at producing a humble, patient subject ready to submit to the patterns imposed by society, writing is identified as producing a «domesticating effect». On the other hand, when the piece of writing projects a reading subject who is alienated from the social system, it institutes itself as revolutionary or at least socially threatening. When writing creates a sense of contiguity, totality and closure based on a stable and centred subjectivity, the domesticating effect is produced. However, subjective instability, discontinuity and open-endedness favour the adoption of a critical position in the reader. Such an opposition stands for the difference between passivity and activity, between dogmatism and critical flexibility in the way in which the subject positions himself in reference to his particular historical circumstances. Smith's and Phillips's postmodern novels, from their different standpoints, acknowledge the above postulates by offering alternative subject positions from where the reader can asses past and present historical circumstances in which power relations are involved avoiding the closure of dogmatic viewpoints.

Postmodern cultural productions eschew dogmatism by simultaneously employing and criticizing inherited traditions as seen in the use of realistic narrative conventions in the novels under scrutiny. The novelty in Smith's and Phillips's view of realism lies in their keen understanding of its ideological implications. Both writers see realism as a system of representation which simultaneously reflects and grants meaning within society. By inscribing and subverting the traditional realistic mode at the same time, these novels reflect the postmodern preoccupation with representation. Borrowing Linda Hutcheon's words (1999: 7), we can say that Smith and Phillips are interested in «how we see ourselves and how we construct our notions of self, in the present and in the past». Their novels reflect a preoccupation with historical circumstances and their aftermath and have political significance as long as they enact a critique of domination and exclusion in the context of imperial policies.

A concern with the individual and the value conferred on the subject as origin of meaning is a central issue inherited from the realist tradition that is both deployed and challenged in The Nature of Blood and White Teeth since such postulates are contrasted with a recognition of the effacement of subjectivity under the domineering influence of cultural models. The co-presence of the ideas described implies an opposition between individual autonomy and the supremacy of cultural structures among which language stands as the paradigmatic model. While the narrators in both novels may use language to create the effect of the real, the presence of irony superimposes a further critical meaning. 
However, irony produces a very different effect in accordance with the tone that prevails in each of the novels. As mentioned above, Linda Hutcheon (1999: 10) acknowledges, two versions of postmodernism can be recognized: one of «apocalyptic despair» and another of «visionary celebration». Bitter irony is employed in Phillips's The Nature of Blood to scourge at the negative aspects of the modern inheritance with the resulting tragic perspective while Zadie Smith's comic approach in White Teeth deploys a light ironic view on the contradictions that beset the current postmodern circumstances. Both novels deal with the distribution of power within society as seen from a postmodern perspective but while Phillips's focuses on the tragic consequences of the attempt to impose hierarchies and build insurmountable barriers between ethnic groups, Smith's rescues the value of heterogeneity, border crossings and a tolerant attitude in the encounter with the other.

Although human intolerance and unfair distribution of power are as old as history itself, we can trace their modern version to a mistaken application of the principles of $18^{\text {th }}$ century Enlightenment, a philosophy that owes its basic postulates to Decartes' rationalism and to the developments of the $18^{\text {th }}$ century Enlightenment philosophy. According to Kant, as read by Foucault (1984: 34), the «Enlightenment is a process that releases us from the status of "immaturity". And by "immaturity", he [Kant] means a certain state of our will that makes us accept someone else's authority to lead us in areas where the use of reason is called for». The successful application of reason through appropriate methods would help humanity achieve the goals of incontestable truth, freedom from ignorance and superstition and a deserved happiness. The optimistic view that resulted bred the conception of history as a record of progress and led to general reliance on science and technology as the basis for an industrial society which would offer the answers that human beings were in search of. Although we can recognize a historical origin for modernity, the present article, in agreement with Lyotard (1979), Bauman (1987), and Foucault (1984), considers modernity more as an attitude than as a historical period. This means that modernity and postmodernity are inextricably connected and co-exist in a permanent state of tension. It also means that however much we may struggle against it, modernity is part of a heritage which Western civilization cannot escape, must recognize and understand.

According to Docherty (1993: 5), the problem with the Enlightenment is not so much its theoretical principles as its practice. In the course of its history, since its birth in the $18^{\text {th }}$ century to its climax in the $20^{\text {th }}$, the principles suffered a transformation as to their application to the point that reason was changed from a valid instrument into an end in itself. It is by this process that «[r]eason becomes no more than a discourse, a language of reason (mathematics), which deals with the "foreign" matter of reality by translating it into reason's own terms; and something — non-conceptual reality itself -- gets lost in the translation» (6). This process cannot be accepted as a means of knowing reality, it is a mere projection of the rational structure of the mind on the world. What is thus obtained may be called knowledge but is no more than a reflection of the very laws that govern the mind. Whatever is not amenable to these laws will forever be left out of this kind of socalled knowledge. The human mind's desire to control and dominate may be formally satisfied in this way though such power over nature is no more than an illusion. In Docherty's (1993: 6) terms what this kind of knowledge «...does give in the way of pow- 
er is, of course, a power over the consciousness of others who may be less fluent in the language of reason». «From now on, to know is to be in a position to enslave». This distortion of the originally enlightening use of reason, completely transforms the demystifying aims of the $18^{\text {th }}$ century movement to turn them into «the locus of ideology» (8).

Together with its confidence in progress and the apotheosis of science, modernity dreamt of an exemplary Western model of life which inevitably led to ethnocentrism. Science, unlimited progress and ethnocentrism are ideological constructions that can be interpreted as central metanarratives born out of the Enlightenment in its distorted application. In the $19^{\text {th }}$ century, to be modern was a highly valued quality and the present was always the highest point of development in the history of humanity. In this context, nations who did not reach the standards of scientific and technological development of the central European states were condemned as inferior and in need of authoritative guidance. This mode of thought evolved into imperial policies which explained political and military intervention and settlement in terms of moral duty. Intellectuals, as much scientists as politicians, legitimised this practice on the basis of the universal validity of the principles applied. As Bauman (1987) sustains, the paradigmatic figure of the modern intellectual is that of the legislator conceived as a human being who has the knowledge, the capacity and the power to impose his judgement and who is certain of the superiority of the values on which his clear view is sustained and in comparison with which other forms of life are seen as primitive. Among the assumptions taken for granted by this position, which Bauman (1987: 120) recognizes was sustained during a couple of centuries by «the northwestern tip of the European peninsula», he mentions that «West was superior to East, white to black, civilized to crude, cultured to uneducated, sane to insane, healthy to sick, man to woman, normal to criminal, more to less, riches to austerity, high productivity to low productivity, high culture to low culture». It is in this fashion, through the imposition of hierarchies, order and a harmonious unity that the Enlightenment becomes totalitarian and «...Reason [becomes] racist and imperialist, taking a specific inflection of consciousness for a universal and necessary form of consciousness» (Docherty 1993: 13). What is good for the Western modern intellectual cannot fail to be good for the whole of humanity. From this universalising spirit countless injustices have been committed.

On the lines of Docherty's idea, Adorno and Horkheimer sustain that the Cartesian dichotomy of subject and object, leading to the need of reason to control the world, eventually turned its power against itself and directed human beings to the «...repression of those elements of human nature that do not correspond to the rigid system of instrumental reason» (in Wulf Kansteiner 2004: 196). The application of instrumental rationality in isolation from moral values is, according to these authors what gave rise to the «...selfdestructive dynamics...» of the holocaust. The otherwise positive achievements of science in the direction of efficient use of resources and the satisfaction of human needs through the development of technology resulted in the empowering of the Nazi regime towards the destruction of millions of victims. The result was the use of bureaucratic industrial methods for the purpose of mass extermination. Eric Santner describes Auschwitz as «a sort of modern industrial apparatus for the elimination of difference» (in Lindenfeld 1997: 14). There is to my mind no doubt that this deviant application of the faculty of reason was at the service of an evil-directed ideology based on intolerance and prejudice as is exemplified by the Nazi identification of Jews with vermin or rats thus 
classifying part of humanity as non-human. As Young (2002:93) sustains, from the universalist and egalitarian philosophy of the Enlightenment, we move to a recognition of difference and inequality in the $19^{\text {th }}$ century. This position was fostered by the economic needs of the expansionist policies of the emerging empires. The moral grounds on which the imperial enterprises were based were the superiority of the white race as the originator of Western civilization and the consequent responsibility to bring the light of reason and advancement to backward corners of the earth peopled by inferior races. Simultaneously, within the nation states, the preservation of racial purity dictated policies of alertness and supervision to avoid miscegenation leading to the creation of ghettoes, to the fostering of diaspora policies or to more active intervention through actual extermination of the unwanted, minority race. The fear of miscegenation has been as strong in reference to the Jewish as to the black in the course of history. The white race being taken as normality, deviations tended to be ideologically identified «with other forms of sexual and social perversity as degeneracy, deformation or arrested embryological development» (Young 2002: 180).

If in the context of colonialism, the figure of the black is objectified as merchandize for the benefit of the master race, ostracized and denigrated, the situation of the black, feminine subject is still more definitely oppressed as a victim of both racism and patriarchy. As goods in the slave trade and as objects of the white male sexual desire, black women were twice subjected and personally obliterated. The fate of the black, the Jews and women can be assimilated as victims of ideologically infused cultural practices that exercised their potent influence in the course of history. Victimization of Jews and women have probably the oldest history in the west through Christian and patriarchal ideological positions. It is no simple coincidence that racist thinkers such as Otto Weininger who equated women to «non-entities» and qualified them as «the sin of man», should also describe Jews as «Womenly men» as a form of contemptuous devaluation (in Ellman 1965: 477). On the other hand, the black diaspora has a more recent development in the context of modern imperial policies. In all cases, however, we can identify a similar philosophical substratum which highlights hierarchical distinctions that become dogmatic and normative with the subsequent totalitarian effect.

Caryl Phillips in The Nature of Blood exemplifies the melancholic view of the postmodern male faced with the failure of the great metanarratives of the Enlightenment in which modern men still believed. The optimistic project of the $18^{\text {th }}$ century with its ideals of equality and solidarity and the centrality of reason as the means to achieve unlimited progress for the betterment of the bulk of society confronted the moral dilemma of utter failure as a consequence of the historical events of the last two centuries. The tragic view of Phillips's novel appears in this context as an attempt to come to grips with such colossal failure and to exorcise the evils committed under the influence of distorted concepts derived from mythological constructions that institute themselves as the founding principles that sustain racism, ethnocentrism and diaspora.

Several of the characteristics common to postcolonialism and postmodernism can be identified in Phillips's novel. This is the case of the break with the metanarrative of the Enlightenment as exemplified in The Nature of Blood in the distrust in reason as a reliable means to arbitrate in social situations. The same may be said of the rejection of the unitary conception of history and of the belief in linear progress as symbolized by the 
general organization of the novel with its paradigmatic treatment of incidents belonging to different times and places such as the account of the $15^{\text {th }}$ century Jewish persecution, of Renaissance racial discrimination and of the Jewish holocaust in the $20^{\text {th }}$ century. The criticism of dogmatism: fixed, inflexible positions which deny difference is equally present in postmodernism and postcolonialism and is exemplified in the novel by its concern with giving a voice to alienated minorities. Both postcolonialism and postmodernism reject dogmatic positions as well as the principles of a centred historical continuum. The Nature of Blood symbolically adheres to these principles through the critical portrayal of the suffering of discriminated social groups (black, Jewish, women) under the domineering influence of proud, phallocentric and expansive nation-states $\left(15^{\text {th }}\right.$ century Venice, $20^{\text {th }}$ century Germany, and Israel).

Phillips's adherence to both postcolonial and postmodern postulates places him mid-way between militant postcolonial defence of those who are subjected to abuse under totalitarian regimes and postmodern philosophical wonderings on the inevitability of inertia, and the compulsion to repetition. In the Nature of Blood the search for new, imaginative responses to the problematic of difference leads to the reality of the Israeli state which is presented as incapable of materializing the dreams of peaceful co-existence and unavoidably repeating the mistakes of previous international experiences. The fate of the characters involved in the different narrative lines (suicide, execution or extermination en masse) does not warrant an optimistic view of the «benefits of cross-cultural potentials» (Ledent 2004: 166) of social encounters in exile. The only exception is the character of Stephan who survives the general violence. However, in spite of his wholehearted emotional commitment with the task of repatriation of the Jews for the building of the new state of Israel, he remains lonely and dispirited once he settles in the new «home» which he helped to build with so much suffering, struggle and loss.

Although both postmodern and postcolonial claims can be discovered in Phillips's novel, a certain degree of tension is manifested in the relationship between the underlying confidence in the truthfulness of individual accounts of subjectivity - philosophically based on a modern belief in the self as origin of meaning - and the de-centredness, disruption and dispersal of meaning — philosophically based on what Ledent, 2004: 167, calls the postmodern «metaphysical malaise»— that characterizes Phillips's narratological approach with its break in spatial, temporal and logical contiguity. This unresolved tension is in fact central to the postmodern movement itself, which is still somehow bound to the modern humanist conception of the subject as the centre and origin of meaning. However, mimesis as unique, universal, uncontested, and total meaning is here subverted by the simultaneous presence of multiple voices internal or external to the action, subjective or objective in their perspective and coming from a variety of generic discourses. In this way, complicity does not ally itself with compromise and the work of art both enacts and contests the search of authenticity in autonomous, individual expression. The final message seems to be that, in spite of much human investment on the part of the individual who would not submit or lose hope in the most extreme situations, there is still a long way to go in the pursuit of the construction of a socio-political system that allows for the realization of tolerant acceptance and openness to otherness. The tension between hope and despair in the novel may also account for an ambiguous response on the part of the readers who might find themselves both emotionally involved with the fate of the pro- 
tagonists as well as alienated and confused in the process of reading by the profusion of interweaving story lines and the variety settings in this highly complex text.

In its uneasy wavering between centredness and de-centredness, between confidence in the individual self as origin of assertive meaning and reliance on language and culture as conveyors of a sense that evades subjective control and disrupts individual intentions, The Nature of Blood is a good example of the workings of postmodern art as defined by Linda Hutcheon. According to the Canadian theorist postmodernism «...at once inscribes and subverts the conventions and ideologies of the dominant cultural and social forces of the twentieth-century western world» (1999: 11).

Although recurrently dealing with historical circumstances, the novel avoids the imposition of a central, sterilised historical line to contribute with a number of individual de-centralized sources of meaning with the purpose of a better understanding of the present and the possible construction of a fairer future. The creation of characters whose lives suffer the onslaughts of discrimination and whose feelings and thoughts are intimately recorded, contributes to the possibility of imagining what it is like to fill such social positions and to understand that «racial difference obstructs empathy and makes ethnocentrism inescapable» (Gilroy 2004: 70). The Nature of Blood, with its traditional confessional aspects and its more contemporary extreme narratological experimentation exposes the totalitarian strategies of imperialism so that readers can recognize their belated effects in their own present-day world.

If the world of Caryl Phillips's The Nature of Blood is all about the creation of borders, the erection of barriers that hinder understanding and about the consequent tragic destiny of its characters, Zadie Smith's White Teeth conjures up a magical universe of a very different order. Smith's female view of the postmodern condition recovers the exhilaration of a new freedom in diversity and encodes the present and the immediate past in the genre of comedy. As Hayden White (1999: XXIV) sustains, there is nothing intrinsically tragic or comic in past events: it is the focalizer's perspective that imposes a tone to the narrative. In White Teeth, cultural diversity far from being conceptualized in terms of violent encounters as in Phillips's novel gives rise to a variety of mixings and blendings that sustain harmonious co-existence. Set in post-colonial London, the novel dramatizes the relations between culturally and racially different characters who find themselves in a common land as a result of the economic and political circumstances that have originated present-day Britain.

Postcolonial studies have been traditionally concerned with the undue application of power from imperial centers on colonized nations and with the effects produced on those under subjection. However, owing to the growing process of globalization, the influence of former colonial cultures on the imperial center has been increasingly recognized as equally strong and lasting. The identity configuration of the U.K. can no longer be assessed in the same terms as before the development of the colonial enterprise: the effect of successive immigration waves from former colonial possessions has completely transformed the constitution of the local identity. The result is a multi-cultural nation in which the English ethnicity counts as one of the many identity configurations that share a common ground where the challenge is how to find feasible ways to live with difference. In Smith's novel, the answer to this challenge coincides with Brah's claim that «[t]here is no a priori reason to suppose that cultural encounters will invariably entail 
conflict. Conflict may or may not ensue and, instead, cultural symbiosis, improvisation, and innovation may emerge as a far more probable scenario» (1996: 41). The celebration of difference stands in opposition to its appropriation for political reasons. The latter choice, based on an essentialist conception of identity marks «impervious boundaries between groups» (91) and should be superseded by a view of identities as processes rather than as «reified artifacts» (92). Brah's view of identity as changing subject positions allows for greater flexibility so that «coalitions are possible through a politics of identification, as opposed to a "politics of identity"» (93). The new scenario reformulates the concept of diaspora: the diasporic subject is not only that who has settled down on foreign land but also the subject who «stays put» and receives the influence of the foreign other. Cultural relations in such contexts are seen as «border crossings» which both contribute to subject positions and to de-stabilize reification (209). The interrelation between the different ethnic groups has given rise to a multi-cultural conglomerate where mutual influence effaces hierarchical positions of dominance. Even if theory (Bhabha 1994, Loomba 2002) has recognized the fallibility of colonialism from its initial stages to sustain the fixity and stability of opposing identities, it has now become obvious that neat binary oppositions are philosophically, psychologically as well as sociologically unsustainable.

The concept of cultural purity with its concomitant intolerance is thus rendered obsolete and restricted to the most recalcitrant modernist positions for which homogeneity and uniformity are the rule. Hierarchies and binary oppositions are avoided by the postmodern conceptualization which sustains heterogeneity and relativity to beat ritual naturalization of difference. The climate of ideas described favours tolerance since, according to Bauman (2005: 64), socio-cultural heterogeneity fosters the development of abilities and character traits that allow for the acceptance of difference among humans. The idea of a stable, coherent core to culture is no longer sustainable in a world of ethnic mixing, rapid urban development, and impregnation in the new cultural technologies. Simultaneously, the workings of power in such a cultural medium dissolve traditional dichotomous concepts such as those of dominant/subjected or hegemonic/subaltern as well as conceptualizations in terms of direct confrontation or «vertical actions» in favour of «...the dissemination of the centers, the multipolarity of social initiatives, [and] the plurality of references». The resulting dissemination of power allows for balanced and reciprocal relations as well as for the «movements of affection and participation in solidarity or complicit activities in which hegemonic and subaltern groups [operate]» (García Canclini 2001: 259).

From the very first pages of White Teeth the reader is confronted with a multicultural, postcolonial London constituted by a complex weave of inter-ethnic connections that make clear-cut, black and white distinctions difficult to sustain. This is also a world where discriminatory differences exist and affect the lives of the characters that are keenly conscious of the weight of traditional modes of thought and feeling resulting from historical relations of power. The male protagonists, Archie Jones and Samad Iqbal, are conscious of the hierarchical distinction between Indians and Englishmen inherited from the colonial encounter. However, they find ways to negotiate the imposed discrimination and to build a life-long friendship on the basis of mutual respect and understanding. The valuable human relation established by these characters is paradigmatic of 
a kind of social encounter that accepts and respects difference and avoids hierarchical discriminations. The characters show awareness of the ideological load of language, of the difficulty of evading the strong pull of ingrained socio-cultural classifications. However, through other forms of communication, connected to action and social behaviour, human beings can overcome the burden of prejudice and succeed in establishing effective contact. Similarly, although Samad's wife Aldana harbours discriminatory feelings towards certain ethnic groups, when it comes to actual personal encounters, she finds enough reasons to commend specific individuals. As to Archie's wife Clara, she is unprejudiced enough to become a partner in an inter-racial marriage and their friends, the Chalfens establish close personal connections with both the Bengali Iqbal children and the half West-Indian Irie Jones. Not even the young Millat Iqbal who expresses his hatred against the British and wants to avenge their treatment of his father and family, or Hussein-Ishmael who «had been a victim of serious physical attacks and robbery, without fail, three times a year» and who come together under the banner of KEVIN (an Islamic extremist group) are actually convincing in their professed intentions to initiate violent actions against the host country and its inhabitants. Living in Britain, these ethnically different characters are as committed to their own original culture as to their present site of residence. In varying degrees, both cultures exercise an influence on their social and psychological behaviour. In the case of Samad Iqbal, a believer in cultural roots, the conflict between the two forces is particularly poignant. The identity struggle leads him to separate his twin sons and send one back for a true Muslim education in Bangladesh with very different results from those expected. When Magid returns, he is more English than the English while Millat, the son who stays, becomes a mock fundamentalist terrorist as an active member of KEVIN and in his adolescent identity crisis attempts to take arms against the English scientist Marcus Chalfen. Confronted with this disastrous finale, Samad wonders where he has gone wrong and feels at a dead end, incapable of adapting to his country of residence and conscious of the impracticability of returning to Bengal (It would have been like «chasing your own shadow»WT 407). After so many years in England, Samad knows that his home country is no more than a distant dream. History, though, exercises as strong an influence as the process of transculturation so that the immigrant population of London will be forever wavering between different cultural backgrounds, confronted with the need to cope with a split sense of belonging, the result of an imperial past. As the narrator sustains, «this is the other thing about immigrants ('fugees, émigrés, travelers): they cannot escape their history any more than you yourself can lose your shadow» (WT 466). We could add that they can neither escape the strong influence of the English local culture. The characters are culturally hybrid.

All the central issues that concern the postcolonial experience come to be dramatically represented in the many vicissitudes the characters in White Teeth experiment in the course of their lives: from dogmatism and the consequent discrimination to the pains of diaspora, the duality of hybridity and transculturation and the fear of miscegenation. In spite of the seriousness of the questions involved, the incidents recounted never reach the level of tragedy since tension is released through laughter. While Caryl Phillips unravels his plots through tragic conflict, Smith turns hers into light comedy. The narrator in White Teeth is highly conscious of the humour inherent in human weakness and folly and takes advantage of every turn in the action to relieve tension through acknowledgement 
of absurdity or paradox. Both religious dogmatism and racial intolerance are ridiculed and as the reader laughs, the threatening implications of the building of impermeable borders lose their force. White Teeth contests traditional judgments on beauty and race in the description of Clara, Archie's love: «Clara Bowden was beautiful in all senses except maybe, by virtue of being black, the classical» (WT 23). The tragic seriousness which usually marks the treatment of issues such as immigrant identity and the fear of miscegenation get their cheerful counterpart in White Teeth. In fact the moral of the tale is that purity is unattainable as much for the host culture as for the immigrant. As Alsana says «You go back and back and back and it's still easier to find the correct Hoover bag than to find one pure person, one pure faith, on the globe. Do you think anybody is English? Really English? It's a fairy-tale!» (WT236). This idea is dramatically present in the novel in the fact that the Chalfens who are endowed with the characteristics of Englishness are in fact third generation Jewish immigrants. However, the figure of the hybrid is probably most patently present in the characterization of the twins Millat and Magid who are simultaneously two and one to the point that Irie cannot distinguish between them as the object of her love or identify who is the father of her child. They come to symbolize the two aspects of their father's personality, the transcultural field, the land of no-where where the crucible of identity comes to be realized.

Although racial and cultural intermixture is the main theme of the novel, two metanarratives underlie the central conflict in which the characters are involved. One of them is the metanarrative of science which is identified with the English ethnic group and the Chalfen family. Good heirs of the Enlightenment philosophy, the Chalfens sustain with great conviction their belief in the application of logic to life and in the perfectibility of the human race. This extreme view is counterbalanced by the position defended by Hortense, Samad, and Millat who sustain the religious metanarrative of divine fate. Rather than abide by the supreme power of man, this group of characters ascertains the supremacy of the divine as well as the belief in the presumption of those who attempt to meddle with divine creation. These characters are fatalists: Divine will determines their destiny as well as the course of history and the functioning of nature. On the basis of these fundamental beliefs, to take steps towards the modification of nature as Marcus Chalfen does through genetic experimentation is seen as presumptuous madness, as an attempt to usurp the role of creator who belongs exclusively to God. On the opposite side, those who sustain the infinite capacity of science to develop, consider any obstruction to its progress as a reactionary attitude and a threat to general improvement and wellbeing. The confrontation between these two opposing views eventually brings all the characters and their varied story lines together to converge in the last chapters of the novel. As in previous incidents, the closing event in the novel avoids the resource of open violence. Chance plays its part in the dénoument and the end proves to be only a new beginning. There is no closure or definite resolution; however, what remains clear is that dogmatisms can never offer the expected answer. Archie's double-sided coin will for ever play its game leaving the reader to cope with the duality of the unexpected, the paradoxical, the uncertain, in one word, the hybrid.

The theme of hybridity and that of the fall of the metanarrative of science are intimately connected and have their expression in the form as well as in the content of White Teeth. According to Pieterse (2001:238) 
Hybridity is to culture what deconstruction is to discourse: transcending binary categories. Another account of hybridity is «in-betweenness». Recognizing the in-between and the interstices means going beyond dualism, binary thinking and Aristotelian logic. Methodologically this is the hallmark of post-structuralism and deconstruction; it represents an epistemological shift outside the boxes of Cartesian epistemology. Postmodernism has been a general heading for this change in outlook.

Both the form and the content of the novel reflect a disbelief in the postulates of the traditional Aristotelian view with its reliance on temporal, spatial and logical contiguity. The work is divided into sections which, except for the last, start in the present and move towards the past, thus breaking with the expected linear succession in time with its symbolical connotation of progress and its reliance on the logic of cause as prior to consequence. At the same time, spatial contiguity is dislocated by constant changes of settings from London to central Europe, India or Jamaica. The strong influence of the relation between cause and effect is also avoided through the presentation of characters that are shown as making life choices led by whim or chance oblivious of the strong pull of circumstances. Both Clara and Archie make a clean break with their past and face their life together as if newly born. But the best example is probably Archie's tendency to make decisions in his life by tossing a coin. Equally free from deterministic shaping factors, Magid and Millat take their own turns in life much to their father's surprise. Neither seems to be burdened by past or present circumstances that determine their fate. Identity is here conceived not as the result of unavoidable circumstantial forces but of free choices in a global world which has lost the traditional certainties of the nation-state to move in the direction of a fluid, ever-changing reality where divergent and equally valid options are available. According to Bauman (2006:1-38), velocity, freedom and fluidity are the qualities that mark postmodern society. Human identity has been transformed from a «given» into a «task» and the «irrevocable» and «predetermined» have been superseded by the mobile and the uncertain. The act of living in the present world is best understood in terms of figures like those of the game and the labyrinth «where the layout of the roads may not obey any law» and where «chance and surprise» signal «the defeat of Pure Reason» (138). White Teeth sustains a flexible and humane conception of identity that agrees with the needs of a cosmopolitan, global, urban society.

Zadie Smith's juggling with the principles of Aristotelian logic reflects the postmodern tendency to problematize the easy reliance on the ideologically founded realistic contract. Postmodernism is suspicious of the confusion between representation and reality that naturalism propounded and strives to raise awareness of the constructedness of meaning. This position is reflected in the narrator's frequent interruption of the line of action to introduce metanarrative comments that bare the fictional device. The metanarrative comments are conspicuous enough to alert the reader about the presence of a voice organizing the fictional world. The message that such gestures communicate is that language and conventional forms of representation (such as the realist novel as a genre) create the meaning that they pretend to «merely reflect». «From this perspective, as Linda Hutcheon (1999: 7) sustains, what we call "culture" is seen as the effect of representations, not their source».

Even though White Teeth breaks with the realist contract at the level of general organization through the disruption of the contiguities of space, time and logic and through 
the use of self-reflective metanarrative comments, at the level of each of the episodes, the novel relies repeatedly on the effect of verisimilitude in the delineation of characters and the account of events. It is in this way, according to Hutcheon (1999:15), that postmodern art comes to de-doxify established values and forms of representation that characterize the modern. The postmodern mode of representation both uses and abuses, inscribes and subverts previously established genres to deconstruct generally recognized values and alert the reader to ideologically naturalized constructions.

The high hopes raised by the humanitarian principles of the Enlightenment philosophy sustained much of human endevour well through the twentieth century when they were dramatically shattered by the successive tragedy of the two world wars and their many atrocities. An inevitable reaction of critique to modernism as the heritage of the Enlightenment ensued and the postmodern movement was born from its midst. The primacy of reason was questioned, especially in its manifestation as a disembodied tool isolated from ethical principles, at the same time that other forms of connecting with the world were rescued from devaluation. Postmodernism and postcolonialism became the site of philosophical discussions that aimed at redressing the evil excesses of modernity as a distortion of the originally enlightened use of reason. Intellectual reaction to such fundamental epistemological issues have varied from melancholia at the fall of the great original hopes of indefinite progress to vital, energetic reaction for the building of new horizons. Caryl Phillips's The Nature of Blood is a manifestation of the former attitude while Zadie Smith's White Teeth can illustrate the latter. While Phillips's novel is an attempt to come to grips with the failure of the great humanistic dream and tries to exorcise the evils committed under mythological constructions, Smith's piece celebrates the birth of a new world born out of the ashes of the old. While The Nature of Blood deplores the building of barriers and the imposition of borders between ethnic, racial or religious communities, White Teeth rejoices in blendings and crossings that make classifications inoperative and absurd. Although both novels deal with basically the same issues, the effects of discrimination produced by the application of totalitarian policies in a variety of historical settings, the imposition of a tragic or comic form modifies the signification of events (White 1992: 60). Where power imbalance is patent, it highlights different aspects of such events, offers different interpretations and opens new vistas from where the reader can judge his/her own present and past circumstances.

\section{BIBLIOGRAPHY}

Bauman, Zigmund (2005): La Globalización. Consecuencias Humanas. Buenos Aires: Fondo de Cultura Económica.

—, (1987): Legislators and Interpreters. Oxford: Polity Press.

—, (2006): .Liquid Modernity. Cambridge: Polity Press.

BaHBHA, Homi, K (2002): The Location of Culture. London and New York: Routledge.

BAKHTIN, Mikhail (1984): Rabelais and his World. U.S.A: First Midland Book Edition.

BRAH, Avtar (1996): Cartographies of Diaspora. Contesting Identities. London and New York: Routledge.

DoCHERTY, Thomas Ed. (1993): Postmodernism: A Reader. New York: Columbia University Press. EllmanN, Richard (1965): James Joyce. Oxford: O.U.P. 
Foucault, Michel (1984): «What is Enlightenment» in Ed. Paul Rabinow. The Foulcault Reader. New York: Pantheon Books.

García CANClini, Nestor (2001): Hybrid Cultures. Strategies for Entering and Leaving Modernity. Minneapolis: University of Minnesota Press.

GILroY, Paul (2006): After Empire. Melancholia or Convivial Culture? London and New York: Routledge.

HutcheOn, Linda (1989). The Politics of Postmodernism. London and New York: Routledge, 1999.

KANSTEINER, Wulf (June 2004): «Genealogy of a category mistake: a critical intellectual history of the cultural trauma metaphor». Rethinking History, Vol. 8 Issue 2, 193-221.

Ledent, Bénédicte (2002): Caryl Phillips. Contemporary World Writers. Manchester, University Press.

LindENFELD, David (1997): «The Prevalence of Irrational Thinking in the Third Reich: Notes towards the Reconstruction of Modern Value Rationality». Central European History, Vol. 30, Fasc. 3.

LoombA, Ania (2002): Colonialism/Postcolonialism. London and New York, Routledge.

LyOTARD, Jean Francois (1979): The Postmodern Condition: A Report on Knowledge, Manchester, Manchester UP, 1984.

PhILLIPS, Caryl (1997): The Nature of Blood. London and Boston, Faber and Faber.

Pieterse, Jan Nederveen (2001): «Hybridity, So What?: The Anti-hybridity Backlash and the Riddles of Recognition». Theory, Culture and Society.18; 219.

Smith, Zadie (2000): White Teeth. London, Penguin.

VATtimo, Gianni (1990): «Potmodernidad: ¿Una Sociedad Transparente?» in En Torno a la Postmodernidad, G. Vattimo y otros, Barcelona, Anthropos.

White, Hayden (1992): El Contenido de la Forma, Barcelona, Paidós.

_, (1999) Realism Figural, Baltimore and London, John Hopkins University Press.

—, (1985) Tropics of Discourse. Baltimore and London, The John Hopkins University Press.

Young, Robert (2002): Colonial Desire: Hybridity in Theory, Culture and Race, London, Routledge. 